\title{
The True Strong Point of Democratic Firm Management
}

\author{
Bruno Jossa \\ University of Naples, Naples, Italy \\ Email: bruiossa@unina.it
}

How to cite this paper: Jossa, B. (2018) The True Strong Point of Democratic Firm Management. Modern Economy, 9, 1625-1634. https://doi.org/10.4236/me.2018.910101

Received: August 28, 2018

Accepted: October 15, 2018

Published: October 18, 2018

Copyright $\odot 2018$ by author and Scientific Research Publishing Inc. This work is licensed under the Creative Commons Attribution International License (CC BY 4.0).

http://creativecommons.org/licenses/by/4.0/

\begin{abstract}
According to the author, the benefits society would derive from the transfer of corporate decision powers to workers upon the establishment of a democratic firm system include both the disempowerment of capitalists and, most importantly, a powerful impetus in the direction of full democracy. Capitalism is a despotic system enabling capitalists to impose their laws not only on workers, but even on politics and culture has been gaining wide currency. Therefore, one major advantage of democratic firm management is the enforcement of the "one head, one vote" principle in lieu of the "one share, one vote" criterion.
\end{abstract}

\section{Keywords}

Democratic Firms, Democracy, Despotic Capitalism

\section{Introduction}

The substitution of the "one head, one vote" principle for the "one share, one vote" criterion is doubtless a major advantage associated with democratic firm management. ${ }^{1}$ In cooperative firms, the main recipients of the resulting benefits would be the partners themselves, in terms that the exercise of decision-making (i.e. sovereign) powers would give them the satisfaction that comes from ceasing to be subject to decisions made by others. ${ }^{2}$ The plan to wrest workers free from

\footnotetext{
${ }^{1}$ As is known, according to Samuelson, in a perfectly competitive market, it doesn't matter if labor hires capital or if capital hires labor [1]. In the reality of the markets, advantages and disadvantages of the labour managed firms (regards to the capitalistic ones) are long discussed in [2].

${ }^{2}$ Galgano [3] reports that the 'one head, one vote' principle arose in the economic context and was transferred to the political sphere only later on. At the meetings of the earliest joint-stock companies, i.e. the colonial enterprises set up in the seventeenth and eighteenth centuries, resolutions were passed by a majority of the votes cast. It was only in the nineteenth century that this system was gradually replaced by the principle that resolutions were to be passed by a number of shareholders representing a majority of the company's capital. The exact opposite occurred in the political sphere, where the electoral systems vesting voting rights solely in citizens meeting certain property qualifications were gradually replaced by universal suffrage.
} 
their yoke will obviously be welcomed by any true liberal. Hence, it comes as no surprise that when Gramsci's Ordine Nuovo articles aroused the enthusiasm of the pro-council movement during Italy's so-called "Red Biennium”, Luigi Einaudi declared that one of the most urgent issues in his day was restoring the "pleasure" that workers used to draw from their work before it was destroyed in large-size industrial concerns $[4] .^{3}$ "The worker-he wrote-would like to regain control of his work, to know why and how he engages in production and to be given a voice in decisions affecting the way the industrial output will be distributed... Once satisfied, these typically human aspirations may lead to moral elevation since they mark the extension to industry of a principle which is strictly adhered by in most modern countries" [4].

In point of fact, the transfer of corporate decision powers from capitalists to workers would generate benefits for society at large, including the powerful stimulus to political democracy resulting from disempowerment of capitalists. As far as I can see, the latter is by far the greatest of the wide range of benefits flowing from the establishment of a system of democratically managed firms. ${ }^{4}$

Marx held that bourgeois democracy emancipates man only in the political sphere, but not in the material relationships he entertains in society. Specifically, he thought it to emancipate man "as he has been corrupted by the whole organization of our society", as a man who "has lost himself, has become a prey to alienation" and has been "handed over to the rule of inhuman conditions and elements" [7]. From his perspective, therefore, the precondition for the achievement of full and effective democracy was emancipating man within the economic relationships he entered into in his life. This only, he argued, could shield political democracy from the impact of the authoritarian organisational modes prevailing in business enterprises. ${ }^{5}$

Werner Sombart described capitalism as a social order connoted by the confrontation between those in command and those obliged to obey [9], and the view that capitalism is a despotic system enabling capitalists to impose their laws not only on workers, but even on politics and culture has been gaining wide currency. Although it was widely held that "laissez faire would break the arbitrary rule of privilege in the economic sphere and make merit, rather than privilege or charity, the basis of economic reward" [10], in the real world this development has been held back by the despotic essence of the capitalistic market.

${ }^{3}$ Unlike Freud, who emphasized a natural aversion to work in man, Marcuse held that "labour in its true form is a medium for man's true self-fulfillment, for the full development of his potentialities" [5]

${ }^{4}$ In Marx and Engels's own words [6]: “The ideas of the ruling class are in every epoch the ruling ideas, i.e. the class which is the ruling material force of society is, at the same time, its ruling intellectual force. The class which has the means of material production at its disposal has control, at the same time, over the means of mental production, so that thereby, generally speaking, the ideas of those who lack the means of mental production are subject to it".

${ }^{5}$ As argued by Fromm [8], though Marx rated freedom, truth or justice as the supreme values, he hardly ever pronounced these words because his skepticism taught him they were susceptible to misuse. 


\section{The Sway of Capital over Labour}

Discussing the impact of the power of capital in production, Finelli [11] wrote: in capitalism "for the first time in the history of mankind reality came to be shaped by an abstract factor; abstraction itself, trespassing the boundaries of its peculiar domain, logic and cognition, began to build a close-meshed network of economic, practical and, more generally, behavioural, societal and cultural relations in the real world". In a self-managed firm system-he concluded-this abstraction (i.e. capital) will no longer perform this disastrous function.

Taking the cue from Finelli, let me emphasize that the disempowerment of capital and the resulting impulse to fuller democracy are by far the greatest advantages that society at large would derive from the establishment of a worker-controlled firm system. In point of fact, the potential of such a system to free society from the need to bend to the wills and interests of large capitalists goes to explain why Marshall held cooperation to have "a special charm for those in whose tempers the social element is stronger". In a cooperative-he wrote-the considerations inducing individuals to engage in business, however strong, must "rest in a great measure on ethical motives" [12].

This leads me to endorse Rosanvallon's conclusion that industrial democracy is "the notion from which we may start out in rethinking and fine-tuning our idea of traditional, i.e. parliamentary democracy" [13].

The advantage that this paper is designed to underscore will appear palpably clear if we picture to ourselves an economic system which is in a preponderating way (if not exclusively) formed of democratic firms. Thanks to the (virtually total) disempowerment of capitalists, political democracy in such a system would become fuller and more effective than it has ever been in any country down to this day. Whoever has given his thoughts to the insoluble conflict between genuine democracy and the power of wealth will easily appraise the importance of democratic firm control. The media, including television and the press, would no longer be subservient to the interests of their owners, nor would they be monopolized by any one (if nothing else, not by a single individual).

This claim was forcefully advanced by $M$. Adler in a study of the distinction between "political democracy" and "social democracy". The former, he argued, and all the other models of society which are generally described as democratic are actually forms of dictatorship since the "general will" they are said to reflect is merely the expression of the interests of the power class and the underlying rationale is the liberalist principle of the atomization of society into abstract individuals. The latter only, he concluded, is a genuine model of democracy, but it can only materialize in a classless society [14].

More recently, a stout advocate of industrial democracy such as Noam Chomsky has remarked that "of all the crises that afflict us, the growing democratic deficit may be the most severe" [15].

In an analysis of freedom under capitalism, Huberman and Sweezy raised a set of questions. "Do we really tolerate all political and economic dissenting opi- 
nions? In ordinary times, it is true that we do not clap liberals or radicals in jail. But what happens in times of great tension, for example? "Isn't it also true-they went on to ask-that jobs, power and prestige almost always to go those who do not dissent, those who are sound and safe?" [16]. According to the well-known Italian political commentator Gustav Zaghebrelsky [17], democracy is the form of political substance, but "what remains when the substance is destroyed is merely an empty shell, a deceiving simulacrum".

Capitalism is marred by economic inequalities which breed political inequality. While it is true that each citizen is entitled to cast a vote, it is a fact that high-income individuals wield far more political power both because they control the media and because they can bribe politicians into acting in their interests. Exploring the pervasive impact of financial markets on US politics in a 2010 book entitled Freefall, Stiglitz argued that even after the crisis of 2008 corporations operating in financial markets kept bankrolling the electoral campaigns of either party with contributions worth hundreds of millions of dollars and that through this practice they were able to influence their political agendas both directly and indirectly (p. 60).

One effect of the unequal distribution of political power is that hardly any issues of concern to the more disadvantaged citizens will enter the political agenda. Although it is the task of politicians to deal with problems and bring them to a satisfactory solution, it is the class in power that decides what they will stand for. ${ }^{6}$ Examples in point include the establishment of publicly-run creche facilities, which low-income families rate as one of their top priorities, ${ }^{7}$ or-to mention an issue associated with the working hypothesis of this paper-the need to introduce democratic firm management. Why has this issue never been put to the vote or, in a least-case hypothesis, made the object of earnest discussion? ${ }^{8}$

\section{The Bourgeoisie Is in Contradiction with Itself}

Decisions made in line with the "one share, one vote" criterion are irredeemably at odds with the principles of democracy to which the bourgeoisie is used to paying lip-service.

On the subject of democracy, Lukàcs wrote that the mere existence of a scientifically acceptable solution is of no avail because "to accept that solution, even

${ }^{6}$ According to Bettelheim [18], the task on which the bourgeoisie is mainly engaged is preventing workers from rising to power.

${ }^{7}$ The establishment of a "Social Market Economy" right within the existing capitalistic system is clearly unworkable. In the words of the Italian historian Giuseppe Galasso, "the call for a 'Constitutional Welfare State' or the yearning for a vaguely defined if not mythical 'Social Market Economy' are instances of stereotyped thinking which have in common an outdated conception of 'the social', while attributes such as 'constitutional' and 'market' betray a deep but misguided reverence for the dreams that some ideologues used to cherish." To refute Galasso's argument, let me object that it may be relevant to capitalism, but not to other possible models of publicly controlled market economies.

${ }^{8}$ The line of reasoning adopted so far is clear evidence that while Marx was doubtless inimical to capital, it is hardly possible to assume that his determination to provide evidence of the exploitation of workers in any capitalistic system he deduced his notion of socialism from his theory of value by way of philosophical speculation [19]. 
in theory, would be tantamount to observing society from a standpoint other than that of the bourgeoisie" and "no class can do that-unless it is willing to abdicate its power freely" [20]. The class consciousness of the bourgeoisie-he argued [20] - is "cursed by its very nature with the tragic fate of developing an insoluble contradiction at the zenith of its powers". As a result of this contradiction, this class must annihilate itself. Historically-he went on to argue-this tragedy is reflected in the fact that "even before it had defeated its predecessor, feudalism, its new enemy, the proletariat, had appeared on the scene. Politically, it became evident when, at the moment of victory, the "freedom" in whose name the bourgeoisie had engaged in its battle against feudalism was transformed into a new repressiveness" which in the mind of Lukàcs was capitalistic exploitation, but which I prefer to equate with the denial of voting rights to workers in firms.

To understand why the bourgeoisie is slow to realize the conflict between the opposition to industrial democracy and its declared principles, suffice it to consider that "when capitalism was in the ascendant... even the ideological exponents of the rising bourgeoisie acknowledged the class struggle as a basic fact of history... In proportion as the theory and practice of the proletariat made society conscious of this unconscious, revolutionary principle inherent in capitalism, the bourgeoisie was thrown back increasingly onto a conscious defensive" [21].

\section{Notes on Historical Materialism}

To enlarge on the foregoing reflections, it is worth providing a few comments on the materialist conception of history, which Lenin rated as "one of the greatest achievements in scientific thinking" [22].

It is widely held that one of Marx's ground-breaking contributions to economic thought was the introduction and definition of notions such as production mode, productive forces and production relations. In a 1935 paper weighing the merits and shortcomings of Marx's political economy approach against those of orthodox economic theory, Oskar Lange argued that the undeniable deficit of Marxian theory in matters of pricing and recourse allocation was more than outweighed by invaluable insights on the way economic life is organized, the division of society into classes and the existence of different production modes. Most importantly, he concluded, Marx set out to clarify the laws which govern the evolution of human society in a long-term perspective. According to Lange, the choice of class division as the starting point for his analysis of society made it possible, for Marx, to foreground those aspects that mark out capitalism from other forms of economic organization [21].

Lange's unconditional commendation of Marx's achievement in these areas was downscaled both by Corrigan, Ramsay e Sayer (CRS) in a seldom quoted 1958 book and by Sweezy in an important paper dating from 1981. Whereas these authors do not deny the importance of the notion of production modes, they do not share Althusser's view that one of Marx's farthest-reaching contri- 
butions to science is the formulation of a general law capable of explaining how production modes emerge, assert themselves and die out. In support of their arguments they report a passage from Marx and Engels's German Ideology which runs that "empirical observation must in each separate instance bring out empirically, and without any mystification and speculation, the connection of the social and political structure with production" and which they read as ruling out the existence of a single law governing a unitary historical course behind different modes of production. Marx and Engels's laws-they go on to argue-are only relevant to the capitalistic production mode, and with respect to other production modes there are no a priori reasons for rating production as the primary driving force behind change [23]. Neither the well-known base-superstructure relation, nor historical materialism as such-they conclude-are necessarily applicable to all production modes. "The gist of historical materialism, Sweezy argues [24], boils down to the insight that each society has to produce what it consumes and that consumption is a necessary prerequisite for society to reproduce itself".

In point of fact, in the light of passages from The German Ideology where Marx and Engels spelt out that "men are indirectly producing their material life... by producing their means of subsistence" [25] and that "what they are therefore coincides with their production, both with what they produce and how they produce" [25] the interpretative approaches of these authors can hardly be rated as cogent. In an analysis of feudalism conducted further on in the same text Marx and Engels explained that "the production of ideas, of conceptions, of consciousness, is at first directly interwoven with the material activity and the material intercourse of men" and that "morality, religion, metaphysics, all the rest of ideology and their corresponding forms of consciousness, thus no longer retain the semblance of independence" because it is not life that is determined by consciousness, but consciousness by life [25]. ${ }^{9}$

If nothing else, Sweezy's methodological approach offers a welcome opportunity to re-emphasize both my thesis that within a democratic firm system society will be spurred on by the will of humans much more freely than it is at the present day and the resulting conclusion that the insights associated with the materialist conception of history have no bearing on a system of democratic firms. In such a system, life would once again be principally shaped by conscience since the suppression of the power of capital would help workers make their choices in utter freedom and organize society as they think best.

In addition to this, the establishment of a democratic firm system would scale down, if not altogether wipe out, the opposition of the business world to public intervention in the economy.

Having regard to Marx and Engels's argument that, as "the domination of material relations over individuals, and the suppression of individuality by for${ }^{9}$ According to Marcuse, ever since prehistoric times, "repression from without has been supported by repression from within: the un-free individual introjects his masters and their commands into his own mental apparatus" [26]. 
tuitous circumstances, they assumed its sharpest and most universal form" in capitalistic systems, mankind is called upon to work towards "replacing the domination of circumstances and of chance over individuals by the domination of individuals over chance and circumstances" [25], there is ground for concluding that the reversal of the current capital-labour relation which is sparked off by the establishment of an employee-managed firm system would greatly expedite the attainment of this aim.

As long as there are markets, the working of the invisible hand may obviously result in economic crises that can hardly be rated as the expression of the general will, but as soon as the market is freed from the power of capitalists such unwanted turns of events, though still possible, will be far less frequent than they are in capitalistic systems. And from this, it clearly follows that the findings of the materialist conception of history have a lesser bearing on a system of self-managed firms.

To account for the confrontation between Democrats and Socialists, Mazzini wrote [27] that the relations between these groups had traditionally been marred by a misunderstanding which was responsible for the split between the middle and working classes that created the assumptions for the Bonapartist dictatorship and had lasted down to his day. "This misunderstanding-he explained-is caused by a misinterpretation of the notion of socialist system which both groups wrongly equated with socialist theory, that is to say with the principle of association".

"The former group reduced Socialism to a set of maximalist assumptions fleshed out by some theorists; and as these appeared to endorse governmentalism, i.e. a concern with uniform regulation that might inhibit the free development of human personality, they condemned Socialism in the name of freedom.

The latter group thought that the opposition of Democrats to their systems originated from a desire to cancel the founding principle of their movement and, consequently, condemned Democracy for the sake of the principle of association.

This totally baseless misunderstanding is still ingrained in the minds of extremists, a considerable group in the ranks of any political party.

This is the message I wish to bring home when I keep repeating two words which to me are sacred: freedom and association.

Are they not enough to induce us to collaborate as brothers? Once we take a single step forward in the direction of the realization of these two principles, would this not open up material prospects for a peaceful debate on secondary issues?"

\section{State Intervention in a System of Producer Cooperatives}

Recently, Arrow has once again emphasized the extent to which markets are beyond control, while Barro has provided evidence that each piecemeal exten- 
sion of democracy in an industrial economy results in increased redistributive state intervention, i.e. in policies which are doubtless geared towards the commendable goal of furthering democracy and equality, but end up by having an adverse impact on efficiency [28].

Like other laissez-faire liberalists Arrow and Barro hold that public intervention in the form of higher taxation inhibits the achievement of a Pareto optimum. To back up his liberalist approach with experiential data, Barro (op. cit.) reports the findings of a political freedom index (values ranging between 0 and 1) based on the 1960-1990 data of some 100 countries which indicate that countries with an index value above 0.5 were those where growth proved slowest. From his perspective, the relevant survey points to an awkward link between slow growth and political freedom which should induce governments to scale down their interventionist policies.

Still other authors have recently highlighted a correlation between State intervention and clientelism. According to them, clientelism and inefficient State intervention are particularly frequent in comparatively backward countries and the poor quality of public goods there is direct consequence of the practice of governments to buy the citizen's votes by unduly magnifying the public sector through new hires [29] [30] [31].

As the approaches of Arrow, Barro and other laissez-faire liberalists have some basis in fact, they can help us pinpoint a few advantages of a system of producer cooperatives.

The idea that a perfect-competition system achieves a Pareto optimum is undeniably one of the most important insights of economic science. As is well known, however, a Pareto optimum is a situation which maximises well-being only with respect to a specific initial distribution of economic resources and within a system to which the "survival assumption" is found to apply. As a result, if we take as a starting point a Pareto-optimal situation, a new situation with a better initial income distribution will improve the well-being of a community. Indeed, this is the reason why governments attempt to improve income distribution.

These reflections suggest a weighty argument in support of a cooperative system.

If Stuart Mill was right when he contrasted the mechanical rules governing production activities with the socially determined essence of distribution, all such choices as are needed to bring about fairer income distribution patterns can either be made at the cost of hampering the free working of markets and the attainment of Pareto optimums, i.e. through tax bracket adjustments or legislative provisions geared towards furthering equal access opportunities to the more lucrative professions. In the light of this, there is scope for arguing that a democratic firm system which strips capital of its power and control rights is able to ensure fairer income allocation patterns even without acting on the tax system or otherwise interfering with the free working of markets. Options with a negligible impact on market mechanisms include a reform of the educational system, a 
well-organized system of competitive examinations to govern recruitment for public service or the enforcement of a well-concerted succession tax regime. In overall terms, governments should shape focused and goal-specific action agendas providing for State intervention policies capable of enhancing income distribution without encroaching upon the free working of market mechanisms. ${ }^{10}$

Comparable arguments are set forth in a recent contribution by Robinson and Verdier [32]: "A basic source of bad economic policies-the authors write in the opening section-is pressure to redistribute income, which at least in democratic system stems from the fact that political power is distributed more equally than assets and income."

These reflections lead up to the conclusion that provided firms are democratically managed in manners ensuring fairer income distribution patterns, the pressure for corrective State action will gradually ebb away and one of the causes which Robinson and Verdier hold to be responsible for bad political practices will consequently be eradicated.

\section{Conclusion}

Capitalism is a despotic system enabling capitalists to impose their laws not only on workers, but even on politics and culture has been gaining wide currency. Therefore, the benefits society would derive from the transfer of corporate decision powers to workers upon the establishment of a democratic firm system include both the disempowerment of capitalists and, most importantly, a powerful impetus in the direction of full democracy.

\section{Conflicts of Interest}

The author declares no conflicts of interest regarding the publication of this paper.

\section{References}

[1] Jenner, J. (2015) On the Relative Absence of Worker Ownerhsip/Management: A Taxonomy. American Social Science Association Conference, Boston.

[2] Dow, G. (2018) The Theory of The Labor-Managed Firm: Past, Present, and Future. Annals of Public and Cooperative Economics, 89.

[3] Galgano, F. (2007) La forzadelnumero e la leggedellaragione. Il Mulino, Bologna.

[4] Einaudi, L. (1966) Il significato del controllo operaio. Cronacheeconomiche e politiche di un trentennio, Vol. V, Einaudi, Turin.

[5] Marcuse, H. (1954) Ragione e rivoluzione. Ital. transl., Il Mulino, Bologna, 1966.

[6] Marx, K. and Engels, F. (1845) La sacra famiglia. Editori Riuniti, Rome, 1969.

\footnotetext{
${ }^{10}$ In the awareness that the legal "superstructure" of the bourgeois state was a historical necessity, Marx went so far as to argue that no alternative formal criterion for the distribution of property was likely to outperform it even at the early stages of a communist system. In this connection, Galgano della Volpe wrote: "As long as a state-albeit a democratic socialist state-does exist, and as long as there is a social order opposing governors to the governed, there is no way of deflecting from the founding principle that a limit is to be placed on the power that the state should be allowed to wield over the citizens" [33].
} 
[7] Marx, K. (1844) La questione ebraica. In: Marx, K. and Engels, F., Eds., Opere scelte, Gruppi, Editori Riuniti, Rome, 1966.

[8] Fromm, E. (1962) Marx e Freud. Ital. transl., Il Saggiatore, Milan, 1968.

[9] Sombart, W. (1902 e 1916) Il capitalismo modern. Ital. Transl., UTET, Turin, 1967.

[10] Schorske, C.E. (1979) Vienna fin de siècle. Ital. Transl., Bompiani, Milan, 1991.

[11] Finelli, R. (2007) Un marxismo “senza Capitale”. In: Bellofiore, R., Ed., Da Marx a Marx? Maifestolibri, Rome.

[12] Marshall, A. (1898) Elements of Economics of Industry. MacMillan, London.

[13] Rosanvallon, P. (1979) Autogestione, democrazia industriale e democrazia parlamentare. In: VV.AA., Ed., Il potere in fabbrica, Edizioni Avanti!, Rome, 1979.

[14] Marramao, G., (1980) Tra bolscevismo e socialdemocrazia: Otto Bauer e la cultura politica dell'austromarxismo. In Hobsbawm, E.J., Haupt, G., Marek, F., Ragionieri, E., Strada, V. and Vivanti, C., Eds., Storia del marxismo, 5 voll., Einaudi, Turin.

[15] Chomsky, N. (2009) Un mondo ingiusto. In: Internazionale, a. 16, n. 816.

[16] Huberman, L. and Sweezy, P.M. (1968) Introduzione al socialismo, Ital. Savelli, Rome, 1978.

[17] Zagrebelsky, G. (2014) Contro la dittatura del presente. Perché è necessario un discorso sui fini, Laterza, Bari-Rome.

[18] Bettelheim, C. (1969) Sulla transizione tra capitalismo e socialismo. Monthly Review.

[19] Enzensberger, H.M. (1973) Colloqui con Marx e Engels, Ital. Einaudi, Turin, 1977.

[20] Lukàcs, G. (1923) Storia e coscienza di classe, Ital. Sugarco Edizioni, Milan.

[21] Lenin, V.I. (1913) Tre fonti e tre parti integranti del marxismo, in Lenin V. I., 1965, Opere scelte, Editori Riuniti, Rome.

[22] Lange, O. (1935) Marxian Economics and Modern Economic Theory. Review of Economic Studies, 2, 189-201. https://doi.org/10.2307/2967586

[23] Corrigan, P., Ramsay, H. and Sayer, D. (1978) Socialist Construction and Marxist Theory. Monthly Review Press, New York. https://doi.org/10.1007/978-1-349-03131-3

[24] Sweezy, P.M. (1981) Il marxismo e il futuro, Ital. Einaudi, Turin, 1983.

[25] Marx, K. and Engels, F. (1845-1846) L'ideologia tedesca, Ital. 3rd Edition, Editori Riuniti, Rome, 1969.

[26] Marcuse, H. (1955) Eros e civiltà, Ital. Einaudi, Turin, 1964.

[27] Mazzini, G. (s.d.) Politica ed Economia. Sonzogno, Milan.

[28] Barro, R. (1996) Determinants of Economic Growth: A Cross-Country Empirical Study. NBER Working Papers No. 5698.

[29] Wilson, J.Q. (1961) The Economics of Patronage. Journal of Political Econmy, 69.

[30] Gimpelson, V. and Treisman, D. (2002) Fiscal Games and Public Employment. World Politics, 54, 145-183. https://doi.org/10.1353/wp.2002.0003

[31] Calvo, E. and Murillo, M.V. (2004) Who Delivers? Partisan Clients in Argentina Electoral Market. American Journal of Political Science, 48, 742-757. https://doi.org/10.1111/j.0092-5853.2004.00099.x

[32] Robinson, J.A. and Verdier, T. (2013) The Political Economy of Clientelism. Scandinavian Journal of Economics, 115, 260-291. https://doi.org/10.1111/sjoe.12010

[33] Della Volpe, G. (1964) Rousseau e Marx. 4th Edition, Editori Riuniti, Rome. 